\title{
Studies of charging mechanisms in impurity-helium condensates by means of impedance spectroscopy and \\ current spectroscopy
}

\author{
A.A. Pelmenev ${ }^{1,2}$, I.B. Bykhalo ${ }^{1}$, I.N. Krushinskaya ${ }^{1}$, and R.E. Boltnev ${ }^{1,3}$ \\ ${ }^{1}$ Branch of Talroze Institute for Energy Problems of Chemical Physics RAS, Chernogolovka 142432, Russia \\ ${ }^{2}$ L.D. Landau Institute of Theoretical Physics RAS, Chernogolovka 142432, Russia \\ ${ }^{3}$ Joint Institute for High Temperatures RAS, Moscow 125412, Russia \\ E-mail: pelmenevaa@gmail.com; boltnev@gmail.com
}

\section{Received October 24, 2018}

\begin{abstract}
A new simple experimental technique has been elaborated to test applicability of impedance spectroscopy for studying processes during destruction of impurity-helium condensates. Combination of methods of optical spectroscopy, impedance spectroscopy and current spectroscopy to study the destruction processes of impurityhelium condensates has been applied for the first time. Experimental data have demonstrated a rather good sensitivity of the technique and proved formation of charged clusters during a destruction stage of impurity-helium condensates.
\end{abstract}

Keywords: nanoclusters, impurity-helium condensates, impedance spectroscopy, superfluid helium, stabilization of ions and radicals.

\section{Introduction}

The results of recent studies on reactions $\mathrm{N}+\mathrm{NH}_{3}$ in solid nitrogen films [1] have shown that upon a deposition of nitrogen gas passed through microwave discharge onto a cold surface at $3 \mathrm{~K}$ up to $8 \%$ of nitrogen atoms form other species than $\mathrm{N}_{2}$ in solid films. Such species may be neutral or charged, atomic or molecular. The most studied species is atomic nitrogen observable in solid films in each of the lowest states ${ }^{4} \mathrm{~S},{ }^{2} \mathrm{D}$, and ${ }^{2} \mathrm{P}$ [2-4]. Neutral and ionic molecular species $\mathrm{N}_{2}^{+}, \mathrm{N}_{3}, \mathrm{~N}_{3}^{+}, \mathrm{N}_{3}^{-}, \mathrm{N}_{4}^{+}$, were detected and studied in solid nitrogen films and nanoclusters [5-15]. A cation $\mathrm{N}_{5}^{+}$has been synthesized as a part of compound $[16,17]$. There are some detailed reviews of experimental and theoretical works on polynitrogen compounds in the literature [18-21]. Recently the nitrogen anion $\mathrm{N}^{-}$has been observed in clusters of molecular nitrogen and rare gases during destruction of impurity-helium condensates [22]. Impurity-helium condensates are highly porous aerogellike materials formed in the bulk superfluid helium (He II) due to aggregation of impurity nanoclusters [23-26]. Nanoclusters grow in a gas helium jet due to association of impurity particles (atoms and molecules) upon fast cooling $\left(\sim 10^{5} \mathrm{~K} / \mathrm{s}\right.$ ) of the gas jet impinging the He II surface by cold $(T=1.5 \mathrm{~K})$ helium vapors $[27,28]$. Atoms of heavier noble gases ( $\mathrm{Ne}$ and $\mathrm{Xe}$ ) as well as molecules of $\mathrm{N}_{2}$ and
NO were used as impurities at the level of $0.1-1 \%$ to helium gas. A gas mixture passage through a radio frequency (RF) discharge area permits to produce radicals, ions, metastable atoms and molecules by excitation of atoms and molecules and dissociation of impurity molecules. Trapping of radicals on nanocluster surface allows to store high concentrations of stabilized nitrogen and hydrogen atoms [26,29-32]. Intense luminescence and current pulses accompany destructions of impurity-helium condensate (IHC) samples containing high densities of stabilized nitrogen atoms [22,33-35]. Two possible mechanisms of charging impurity nanoclusters were suggested to explain observations of the current pulses [35].

In this paper we present new experimental results obtained by dielectric spectroscopy methods during destruction stage of impurity-helium condensates. A simple experimental technique has been elaborated and manufactured for these purposes. The new results are in good accordance with results obtained earlier by means of optical spectroscopy and current spectroscopy. We have got clear proves that the clusters were charged due to an intense recombination of nitrogen atoms during the IHC sample destruction producing excited molecules $\mathrm{N}_{2}\left(A^{3} \Sigma\right)$ which capture electrons from a substrate and charge the sample fragments [36-38]. Unfortunately, we were unable to get frequency dependence of IHC samples impedance due to destruction 
transiency of samples. Therefore, we were not able to detect ions trapped in nanoclusters. Experimental data demonstrate a rather good sensitivity of the technique and its applicability for studies of processes in either molecular nitrogen or rare gas cryofilms stimulated either by energetic particles or by VUV photons.

\section{Experimental setup}

The method of helium gas jet injection into the He II bulk [39] was used for IHC sample preparation. Our experimental setup has been described elsewhere [31,32]. The cryogenic part of the experimental setup consists of two glass double-walled silvered Dewars. The outer Dewar was filled with liquid nitrogen, and the inner Dewar was filled with liquid helium. The gas mixture consisting of helium and impurity particles (0.1-1\%) enters (with the gas jet flux about of $4 \cdot 10^{19}$ particles/s) the inner Dewar via a quartz capillary cooled by liquid nitrogen. A radio frequency discharge was used for dissociation of impurity molecules and excitation of atoms and molecules. Electrodes placed around the quartz capillary provided a $40 \mathrm{MHz}, 40 \mathrm{~W}$ RF discharge. A gas jet was directed onto the He II surface in a glass beaker placed below the source at the distance of $25 \mathrm{~mm}$ (Fig. 1(a)). The steady-state level of He II in the beaker (with an inner diameter of $22 \mathrm{~mm}$ ) was maintained by a fountain pump located in the liquid helium bath at the bottom of the inner Dewar.

A spectrometer AvaSpec-ULS2048XL-USB2 allowed us to detect emission within the spectral range from 200 to $1160 \mathrm{~nm}$ with resolution $\approx 2.5 \mathrm{~nm}$. Emission from IHC sample under study was fed to the spectrometer by means of optical fibers and vacuum feedthrough. The pressure of helium vapor in the glass Dewar within the range 0-10 kPa was measured with a Rosemount gauge 3051TA2. The thermometer, a $\mathrm{RuO}_{2}$-chip attached to the sensor surface (Fig. 2), was used for temperature measurements in the beaker. Ion currents accompanying the destruction of IHC samples were detected by a ring-shape electrode (Fig. 2(b)) connected directly to a picoammeter Keithley 6485.

To measure an impedance of IHC samples under study have a planar capacitive sensor had been chosen (Fig. 2). Capacitive sensors are often used for dielectric spectroscopy because of their high measurement accuracy and noninvasiveness. The way of IHC sample preparation excludes a possibility to use the simplest versions of such sensors: parallel-plate capacitor and a coaxial cylindrical capacitor. Fringing electric field sensor adopted to the beaker crosssection has been elaborated and hand-made. The main drawback of such a construction is the small penetration length of fringing electric field sensors. The penetration length is comparable with the distance between coplanar electrodes, $0.5 \mathrm{~mm}$ (Fig. 2(a)). An external USB sound card ESI UGM96 (2 independent mono Hi-Z inputs and 2 analog output channels, 24-bit/96 kHz) was used as a sinusoidal signal source (the amplitude $5 \mathrm{~V}$ ) and 2-channel analog-to-digital convertor of an impedance bridge. Such a bridge using the LMS (least mean square) algorithm is suitable for real-time impedance measurements [40]. Free software Visual Analyser [41] was used for data acquisition during experiment. Impedance consists of two parts: a real (resistive) part and an imaginary (reactive) part. The measurement results will be shown as the resistance, $R$, and capacity, $C$, corresponding to real and imaginary parts, respectively. The capacity of the empty sensor was equal to $4.83 \mathrm{pF}$ at room temperature. The capacitance of wires to the sound card was about of $26.65 \mathrm{pF}$.
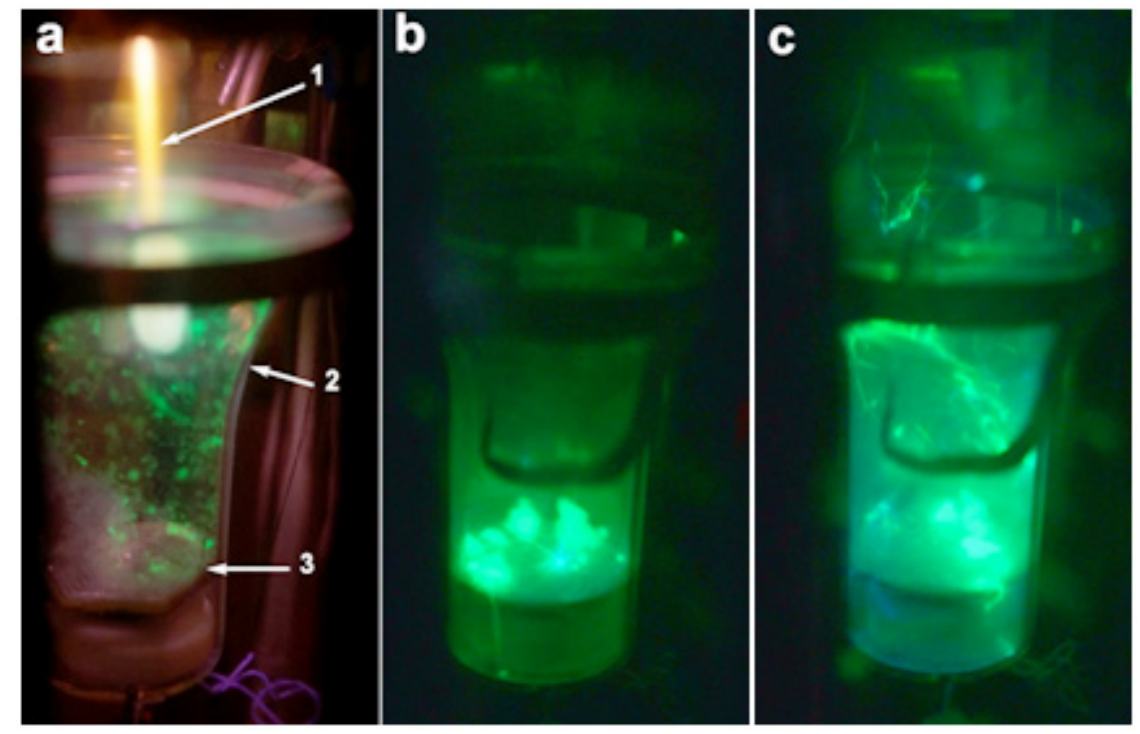

Fig. 1. IHC sample accumulation: gas jet impinging the He II surface (1); glass beaker filled with superfluid helium (2); capacitive sensor (3) (a); glowing fragments of IHC sample during its destruction (b); explosion of the sample fragments (c). 


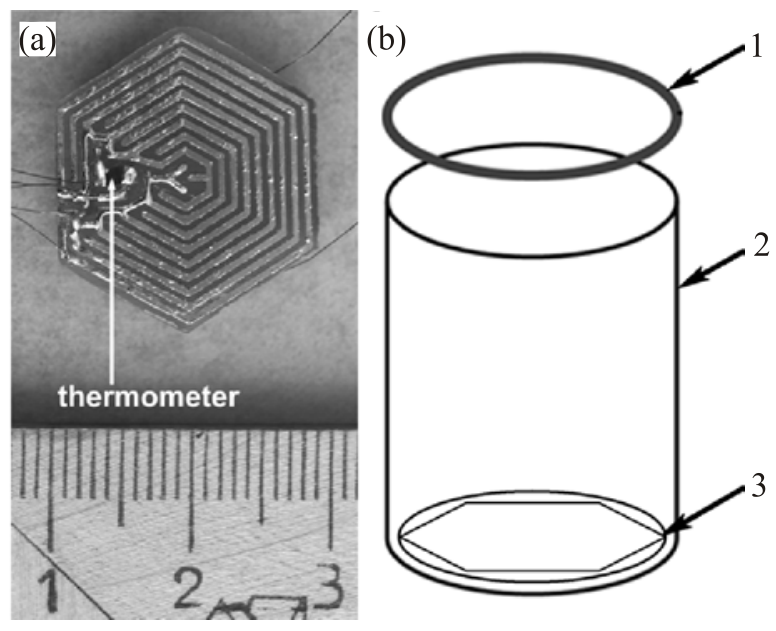

Fig. 2. Size and geometry of the capacitive sensor (a); positions of the ion collector (1) and the sensor (3) above/in the beaker (2) (b).

This acquisition system allowed us to work with the satisfactory signal/noise ratio within the frequency range $500 \mathrm{~Hz}-20 \mathrm{kHz}$. The whole frequency sweep took about of $300 \mathrm{~s}$. We measured the sample impedance every $0.4 \mathrm{~s}$ at fixed frequency (equal 2.7 or $3 \mathrm{kHz}$ ) because of the time restriction during sample destruction. These frequency values were chosen because of the best signal/noise ratio obtained and the shortest time needed for the bridge balance settling.

The efficient length (penetration length) of the sensor has been estimated as $0.55 \mathrm{~mm}$ by slow moving (with a stepper motor) a special glass plate away from its surface. The work area of the sensor is about of $2.54 \mathrm{~cm}^{2}$, therefore, the efficient volume of the sensor was equal to $0.14 \mathrm{~cm}^{3}$.

We weren't able to make measurements of the temperature, current and impedance during RF discharge application because of strong electric field interference.

\section{Experimental results}

First of all, we have determined the capacity of the empty sensor at helium temperatures. The sensor capacity, $C$, is proportional to $C_{0} \varepsilon$, where $C_{0}$ is a geometric factor of the sensor, and $\varepsilon$ is the dielectric constant (also commonly known as the relative permittivity) of material. We have measured the capacity values, $C_{l}$ and $C_{a}$, at $1.5 \mathrm{~K}$ for the sensor in He II, $\varepsilon_{l}=1.0573$ [42], and in helium gas, $\varepsilon_{g} \approx 1$. Then we have determined the sensor capacity

$$
\begin{gathered}
C_{0}=C_{g}=\Delta C / \Delta \varepsilon=\left(C_{l}-C_{g}\right) /\left(\varepsilon_{l}-\varepsilon_{\mathrm{g}}\right)= \\
=0.247 / 0.0573=4.31 \mathrm{pF} .
\end{gathered}
$$

The temporal dependences of the temperature, pressure, luminescence intensity, current, capacity, and resistance during a destruction of sample prepared from $\left[\mathrm{N}_{2}\right] /[\mathrm{He}]=1 / 200$ gas mixture are shown in Fig. 3. One can see from the pressure dynamics (Fig. 3(a)) that liquid helium evaporated

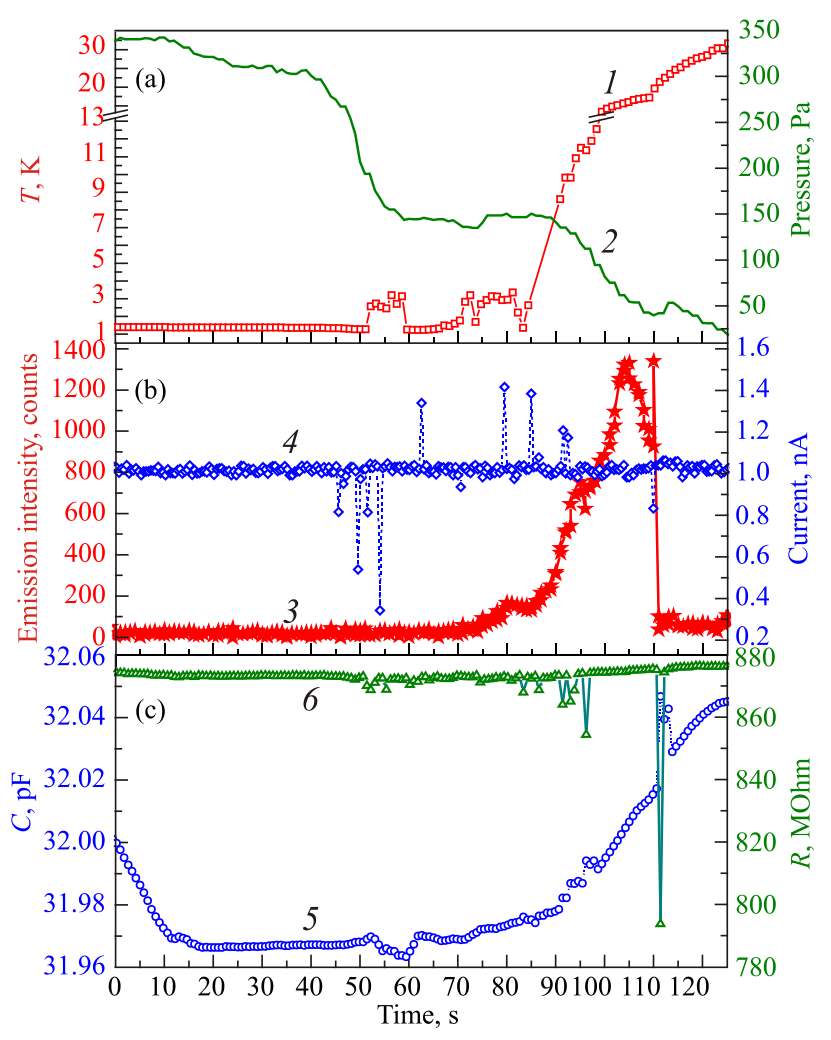

Fig. 3. (Color online) Destruction of sample prepared from $\left[\mathrm{N}_{2}\right] /[\mathrm{He}]=1 / 200$ gas mixture: temporal dependences of the temperature (red squares, 1) and pressure (green line, 2) (a); temporal dependences of the luminescence intensity (red stars, 3) and current (blue diamonds, 4) (b); temporal dependences of the capacity (blue circles, 5) and resistance (green triangles, 6) (c).

from the beaker (there was no liquid helium in the helium Dewar) at $t \approx 40 \mathrm{~s}$. After this moment sharp changes of the pressure reflected collapse of the sample and were accompanied with changes of the other parameters measured.

Luminescence spectrum integrated during destruction of this sample is shown in Fig. 4. The Vegard-Kaplan (VK) bands relate to transitions $A^{3} \Sigma_{u}^{+}-X^{1} \Sigma_{g}^{+}$of molecules $\mathrm{N}_{2}$. The $\alpha$ - and $\delta$-groups of $\mathrm{N}$ atoms correspond to the transitions ${ }^{2} D-{ }^{4} S$ and ${ }^{2} P-{ }^{2} D$. The $\beta$-group of $O$ atoms matches to the transition ${ }^{1} S-{ }^{1} D$. Some additional features have been observed in the spectrum of the most intense flash during the sample destruction. The band at $360 \mathrm{~nm}$ has been recently attributed to polynitrogen molecule $\mathrm{N}_{4}$ [15]. The bands at 291, 307, and $323 \mathrm{~nm}$ correspond to the well known transitions of the $\beta$-system of NO molecules. We observe the spectra of atomic oxygen and molecules containing $\mathrm{O}$ atoms because a helium gas used for experiments contains molecular oxygen as impurity at the level of a few ppm.

The temporal dependences of the temperature, pressure, luminescence intensity, current, capacity, and resistance during a destruction of sample prepared from $[\mathrm{NO}] /[\mathrm{Ne}] /[\mathrm{He}]=$ $=1 / 100 / 50000$ gas mixture are shown in Fig. 5 . One can 


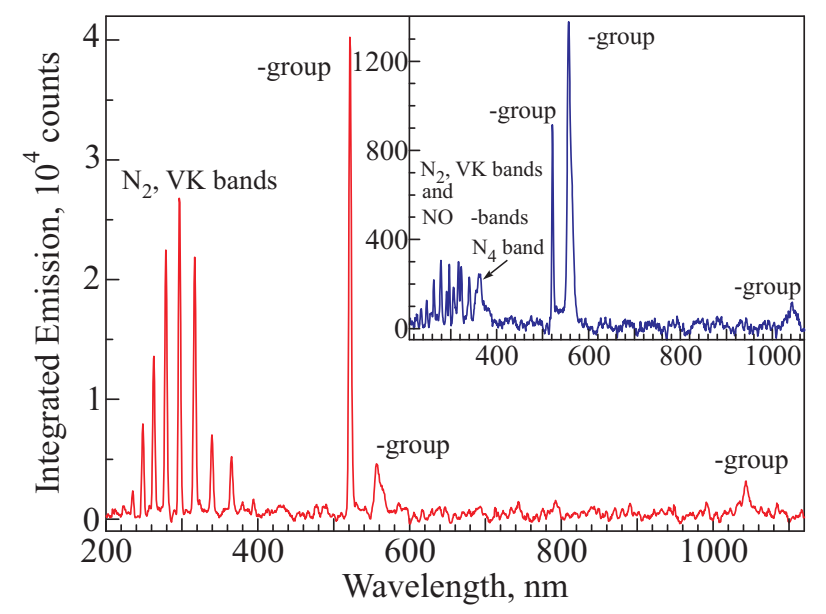

Fig. 4. (Color online) Luminescence spectrum integrated during destruction of sample prepared from $\left[\mathrm{N}_{2}\right] /[\mathrm{He}]=1 / 200$ gas mixture. The spectrum of the most intense flash is shown in the inset.

see from the pressure dynamics (Fig. 4(a)) that liquid helium evaporated from the beaker at $t \approx 35 \mathrm{~s}$. After this moment the pressure value is determined by evaporation of helium atoms from weakly-bound shells of helium around impurity clusters [31,43] and deviate from the saturated vapor pressure values at corresponding temperatures.

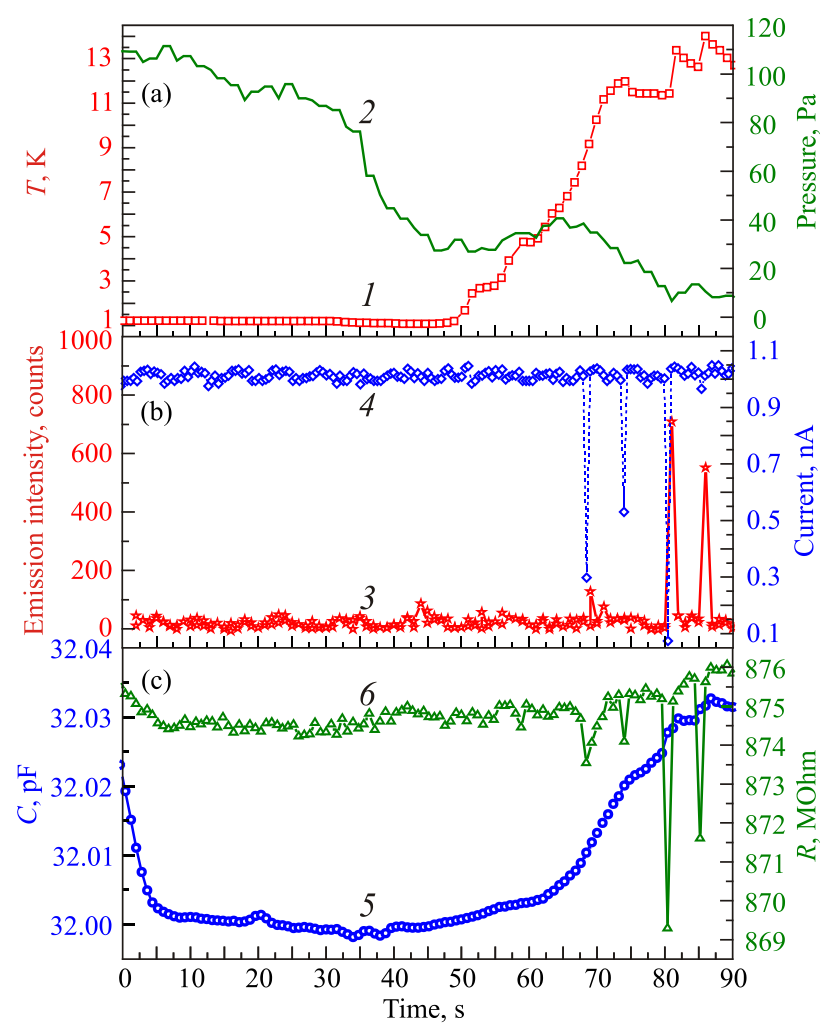

Fig. 5. (Color online) Destruction of sample prepared from $[\mathrm{NO}] /[\mathrm{Ne}] /[\mathrm{He}]=1 / 100 / 50000$ gas mixture: temporal dependences of the temperature (red squares, 1) and pressure (green line, 2) (a); temporal dependences of the luminescence intensity (red stars, 3) and current (blue diamonds, 4) (b); temporal dependences of the capacity (blue circles, 5) and resistance (green triangles, 6) (c).

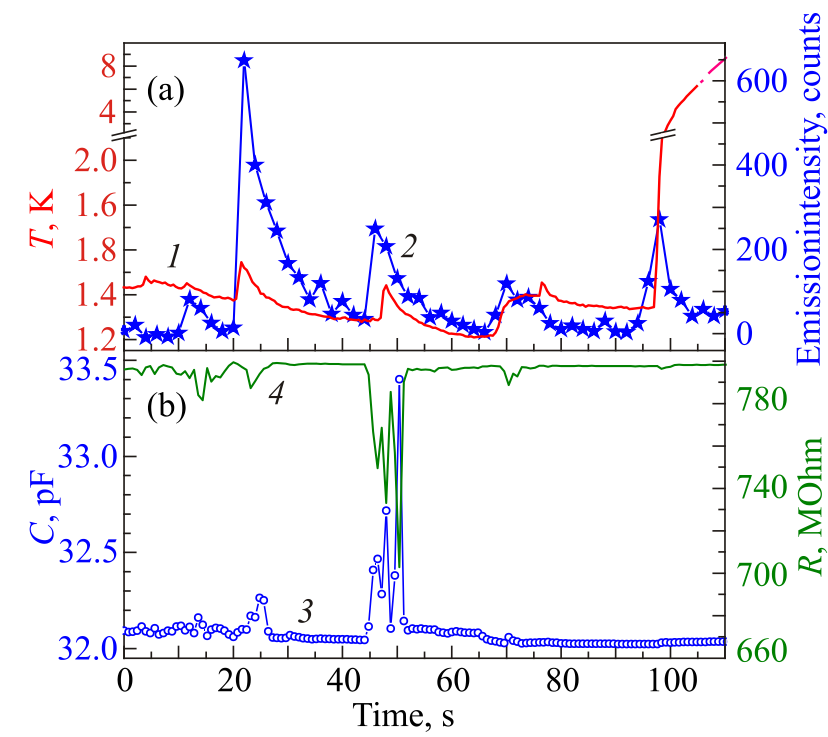

Fig. 6. (Color online) Destruction of sample prepared from $\left[\mathrm{N}_{2}\right] /[\mathrm{Xe}] /[\mathrm{He}]=1 / 1 / 400$ gas mixture: temporal dependences of the temperature (red line, 1) and luminescence intensity (blue stars, 2) (a); temporal dependences of the capacity (blue circles, 3) and resistance (green line, 4) (b).

The temporal dependences of the temperature, luminescence intensity, capacity, and resistance during a destruction of sample prepared from $\left[\mathrm{N}_{2}\right] /[\mathrm{Xe}] /[\mathrm{He}]=1 / 1 / 400$ gas mixture are shown in Fig. 6. It is worth noting very strong responses of both parts of the impedance during explosions of the samples. For instance, the changes of the sensor capacity was about two order of magnitude larger than in the previous cases (Figs. 3 and 5). Samples formed from xenon-nitrogen-helium gas mixtures are very energetic and begin to destroy even in the bulk He II $[30,33]$. The first and second explosions (at $t=22$ and $46 \mathrm{~s}$ in Fig. 6(a), respectively) occurred when the sample fragments were on the sensor surface. The third and forth flashes correspond to explosions of the sample fragments located below the sensor. That is a reason why these explosions made much weaker responses of the sensor.

The luminescence spectrum of the second explosion is shown in Fig. 7. The "green bands" correspond to the $2^{1} \Sigma, 0-1^{1} \Sigma, v^{\prime \prime}$ transitions of $\mathrm{XeO}^{*}$, whereas the band at $595 \mathrm{~nm}$ can be associated with the transitions $\mathrm{Xe}^{+} \mathrm{O}^{-}\left(3^{1} \Sigma^{+}\right)-\mathrm{XeO}\left(2^{1} \Sigma\right)$ or $\mathrm{XeO}^{*}\left(2^{1} \Sigma-1^{1} \Delta\right)$ [44]. The very broad band peaked at $720 \mathrm{~nm}$ is a combination of two bands [44]. The first, at $690 \mathrm{~nm}$, was associated with the transition $\left(1^{1} \Pi-\mathrm{X}^{3} \Pi\right)$ of the $\mathrm{XeO}^{*}$ molecule [44]. The second band matches well to the spectrum produced by an $\mathrm{O}\left({ }^{1} \mathrm{~S}\right)$ atom at the xenon crystal surface [45].

\section{Discussion}

Due to inhomogeneous increase of the temperature within the beaker, different parts (fragments) of the sample explode at different time moments. We can see that the ion 


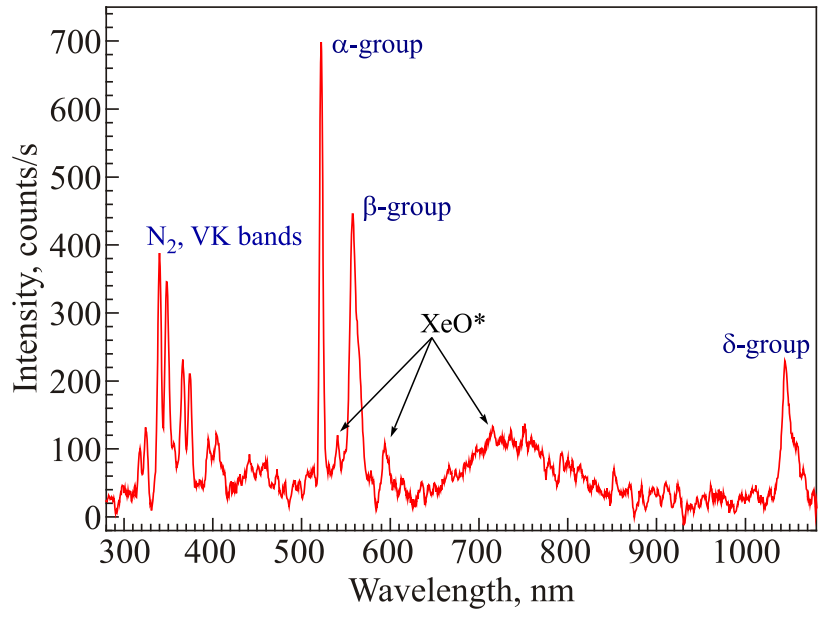

Fig. 7. (Color online) Luminescence spectrum detected during destruction of sample prepared from $\left[\mathrm{N}_{2}\right] /[\mathrm{Xe}] /[\mathrm{He}]=1 / 1 / 400$ gas mixture.

collector detects some signals for every explosion (Figs. 3 and 4) while the planar sensor does either fragment explosions or evaporation of He II, sublimation/deposition of impurity matter occurring exclusively within its efficient volume.

We have observed some bright flashes during destruction the sample prepared from $\left[\mathrm{N}_{2}\right] /[\mathrm{Xe}] /[\mathrm{He}]=1 / 1 / 400$ gas mixture (Fig. 1(c)). The sensor capacity peak changes equal to $1.36 \mathrm{pF}$ has been detected during the explosion of small fragments of the sample with a total volume about of $0.02 \mathrm{~cm}^{3}$ shown in Fig. 1(c) (the corresponding impedance changes are shown in Fig. 6(b) at $t=49 \mathrm{~s}$ ). The dielectric constant changes have been estimated as $\Delta C / C_{0}=1.36 / 4.31=0.317$, and $\Delta \varepsilon=0.317$. The atomic polarizabilities of xenon, nitrogen, and helium are equal to 4.122, 1.13, and $0.205 \AA^{3}$, correspondingly [46]. The polarizability of molecular nitrogen is equal to $1.74 \AA^{3}$ [46].

Let's estimate the density of xenon equivalent to the capacity peak changes $1.36 \mathrm{pF}$ following to the ClausiusMossotti relation:

$$
\rho=\frac{(\varepsilon-1)}{(\varepsilon+2)} \frac{3}{4 \pi} \frac{M}{\alpha \cdot N_{A}},
$$

where $\alpha$ - the atomic polarizability of xenon, $N_{A}-$ Avogadro's number, $M$ - molar mass of xenon, $131.3 \mathrm{~g} / \mathrm{mol}$.

Keeping in the mind the efficient volume of the sensor, $0.14 \mathrm{~cm}^{3}$, we determine the number of xenon atoms in this volume as $N=7.75 \cdot 10^{20}$. The value obtained is much larger than a total quantity of Xe atoms (and $\mathrm{N}_{2}$ molecules) released during the sample preparation $\approx 1.7 \cdot 10^{20}$ and the sample volume was many times larger than its fragment volume. Therefore, we can explain the changes of the dielectric permittivity by appearance of either excited or ionized particles within the efficient volume of the sensor.

In the optical spectrum of the explosion, the Vegard-Kaplan bands of $\mathrm{N}_{2}{ }^{*}$ molecules, the bands at 595 and $720 \mathrm{~nm}$, as well as the "green bands" of $\mathrm{XeO}^{*}$ mole- cules, and the $\alpha$ - and $\delta$-groups of $\mathrm{N}$ atoms, and the $\beta$-group of $\mathrm{O}$ atoms had been observed (Fig. 7). We have no direct spectroscopic observations of ionic species during the sample destruction (Fig. 7) in contrary to some sharp decreases of a real part of the impedance (Fig. 6(b)). Meanwhile the current pulses detected during destructions of IHC samples correspond to charged fragments of the samples under study. As it has been discussed before, there are two possible ways of charging impurity clusters: electrons and positive ions are trapped by the nanoclusters growing in cold helium gas jet passed through a radiofrequency discharge; intense recombination of nitrogen atoms during the IHC sample destruction produces excited molecules $\mathrm{N}_{2}\left(A^{3} \Sigma\right)$ which capture electrons from a substrate [36-38] and charge the sample fragments up to $10^{4}$ elementary charges [35]. The molecules $\mathrm{N}_{2}\left(A^{3} \Sigma\right)$ are always detected through their emission (the Vegard-Kaplan bands) during destruction of impurity-helium condensates containing nitrogen, for example, Figs. 5 and 7. These metastable molecules are responsible for excitation of nitrogen and oxygen atoms stabilized in nitrogen matrix [47] and nanoclusters [48], as well as of NO molecules [49] in a nitrogen matrix. Excited NO molecules can be formed also in result of recombination of $\mathrm{O}$ and $\mathrm{N}$ atoms.

We can summarize that application of impedance spectroscopy for studying impurity-helium condensates have some restrictions: the high porosity, $>90 \%$, of IHC samples $[25,26,28,43]$, and their collapse into non-flat fragments upon liquid helium evaporation [43] strongly affect the sensitivity of the methods. Nevertheless, the results obtained by this way are in good accordance with the data of optical and current spectroscopy. Moreover, the impedance is very responsive to processes accompanied with material sublimation/deposition and appearance of ions in the efficient volume of the planar sensor. Frequency weeping can give more information on ions trapped in condensates. Thus we suggest that impedance spectroscopy is very promising tool to study processes initiated in cryofilms of inert gases either by energetic particles $[6,8-11,13,14]$ or by VUV photons [7,12].

\section{Conclusions}

Impedance spectroscopy method has been successfully applied for study of processes during destruction of impurity-helium condensates.

New experimental results obtained by the method are in good correlations with the results of optical spectroscopy and current detection studies of impurity-helium condensates. The results have proved the impurity clusters charging mechanism through capturing electrons from a substrate by excited molecules $N_{2}\left(A^{3} \Sigma\right)$ which are products of intense recombination of nitrogen atoms during destruction of impurity-helium condensates. 
1. S. Nourry and L. Krim, Phys. Chem. Chem. Phys. 18, 18493 (2016).

2. M.A. Heald and R. Beringer, Phys. Rev. 96, 645 (1954).

3. M. Peyron and H.P. Broida, J. Chem. Phys. 30, 139 (1959).

4. O. Oehler, D.A. Smith, and K. Dressler, J. Chem. Phys. 66, 2097 (1977).

5. A.E. Douglas and W.J. Jones, Canadian J. Phys. 43, 2216 (1965).

6. R. Tian and J. Michl, Faraday Discuss. Chem. Soc. 86, 113 (1988).

7. R. Tian, J.C. Facelli, and J. Michl, J. Phys. Chem. 92, 4073 (1988).

8. C.S. Jamieson and R.I. Kaiser, Chem. Phys. Lett. 440, 98 (2007).

9. J.C. Amicangelo, J.R. Collier, C.T. Dine, N.L. Saxton, and R.M. Schleicher, Mol. Phys. 105, 989 (2007).

10. Y.-J. Wu, H.-F. Chen, S.-J. Chuang, and T.-P. Huang, Astrophys. J. 779, 40 (2013).

11. E.V. Savchenko, I.V. Khyzhniy, S.A. Uyutnov, A.P. Barabashov, G.B. Gumenchuk, M.K. Beyer, A.N. Ponomaryov, and V.E. Bondybey, J. Phys. Chem. A 119, 2475 (2015).

12. J.-I. Lo, S.-L. Chou, Y.-C. Peng, M.-Y. Lin, H.-C. Lu, and B.-M. Cheng, Astrophys. J. Supplement Series 221, 20 (2015).

13. E. Savchenko, I. Khyzhniy, S. Uyutnov, M. Bludov, G. Gumenchuk, and V. Bondybey, Radiation Measurements 90, 1 (2016).

14. E. Savchenko, I. Khyzhniy, S. Uyutnov, M. Bludov, A. Barabashov, G. Gumenchuk, and V. Bondybey, IOP Conf. Series: Materials Science and Engineering 169, 012007 (2017).

15. P.T. McColgan, A. Meraki, R.E. Boltnev, D.M. Lee, and V.V. Khmelenko, J. Phys. Chem. A 121, 9045 (2017).

16. K.O. Christe, W.W. Wilson, J.A. Sheehy, and J.A. Boatz, Angew. Chemie, Int. Ed. 38, 2004 (1999).

17. A. Vij, W.W. Wilson, V. Vij, F.S. Tham, J.A. Sheehy, and K.O. Christe, J. Am. Chem. Soc. 123, 6308 (2001).

18. M.T. Nguyen, Coord. Chem. Rev. 244, 93 (2003).

19. P.C. Samaritzis and A.M. Wodtke, Inter. Rev. Phys. Chem. 25, 527 (2006).

20. E.G. Lewars, Nitrogen Oligomers and Polymers: Superfuels or Chimeras?, in: Modeling Marvels: Computational Anticipation of Novel Molecules. Springer Science+Business Media B.V. (2008).

21. V.E. Zarko, Combustion. Explos. Shock Waves 46, 121 (2010).

22. R.E. Boltnev, I.B. Bykhalo, I.N. Krushinskaya, A.A. Pelmenev, S. Mao, A. Meraki, P.T. McColgan, D.M. Lee, and V.V. Khmelenko, Phys. Chem. Chem. Phys. 18, 16013 (2016).

23. V. Kiryukhin, B. Keimer, R.E. Boltnev, V.V. Khmelenko, and E.B. Gordon, Phys. Rev. Lett. 79, 1774 (1997).

24. S.I. Kiselev, V.V. Khmelenko, and D.M. Lee, Fiz. Nizk. Temp. 26, 874 (2000) [Low Temp. Phys. 26, 641 (2000)].

25. S.I. Kiselev, V.V. Khmelenko, D.M. Lee, V. Kiryukhin, R.E. Boltnev, E.B. Gordon, and B. Keimer, Phys. Rev. B 65, 024517 (2002).
26. R.E. Boltnev, I.N. Krushinskaya, A.A. Pelmenev, E.A. Popov, D.Yu. Stolyarov, and V.V. Khmelenko, Fiz. Nizk. Temp. 31, 723 (2005) [Low Temp. Phys. 31, 547 (2005)].

27. V. Kiryukhin, E.P. Bernard, V.V. Khmelenko, R.E. Boltnev, N.V. Krainyukova, and D.M. Lee, Phys. Rev. Lett. 98, 195506 (2007).

28. N.V. Krainyukova, R.E. Boltnev, E.P. Bernard, V.V. Khmelenko, D.M. Lee, and V. Kiryukhin, Phys. Rev. Lett. 109, 245505 (2012).

29. E.P. Bernard, R.E. Boltnev, V.V. Khmelenko, and D.M. Lee, J. Low Temp. Phys. 134, 199 (2004).

30. A. Meraki, P.T. McColgan, R.E. Boltnev, D.M. Lee, and V.V. Khmelenko, J. Low Temp. Phys. 192, 224 (2018).

31. E.P. Bernard, R.E. Boltnev, V.V. Khmelenko, V. Kiryukhin, S.I. Kiselev, and D.M. Lee, Phys. Rev. B 69, 104201 (2004).

32. R.E. Boltnev, V.V. Khmelenko, and D.M. Lee, Fiz. Nizk. Temp. 36, 484 (2010) [Low Temp. Phys. 36, 382 (2010)].

33. R.E. Boltnev, I.B. Bykhalo, I.N. Krushinskaya, A.A. Pelmenev, V.V. Khmelenko, S. Mao, A. Meraki, S.C. Wilde, P.T. McColgan, and D.M. Lee, J. Phys. Chem. A. 119, 2438 (2015).

34. I.N. Krushinskaya, R.E. Boltnev, I.B. Bykhalo, A.A. Pelmenev, V.V. Khmelenko, and D.M. Lee, Fiz. Nizk. Temp. 41, 541 (2015) [Low Temp. Phys. 41, 419 (2015)].

35. A.A. Pelmenev, I.N. Krushinskaya, I.B. Bykhalo, and R.E. Boltnev, Fiz. Nizk. Temp. 42, 289 (2016) [Low Temp. Phys. 42, 224 (2016)].

36. P. Stracke, F. Wiegershaus, S. Krischok, and V. Kempter, Surf. Sci. 396, 212 (1998).

37. N. Lorente, D. Teillet-Billy, and J.-P. Gauyacq, Surf. Sci. 432, 155 (1999).

38. J. Marbach, F.X. Bronold, and H. Fehske, Eur. Phys. J. D 66, 106 (2012).

39. E.B. Gordon, L.P. Mezhov-Deglin, and O.F. Pugachev, JETP Lett. 19, 63 (1974).

40. G. Steber, QEX 5, 41 (2005).

41. Visual Analyser Project at http://www.sillanumsoft.org/

42. R.J. Donnelly and C.F. Barenghi, J. Phys. Chem. Ref. Data 27, 1217 (1998).

43. R.E. Boltnev, E.B. Gordon, I.N. Krushinskaya, M.V. Martynenko, A.A. Pelmenev, E.A. Popov, V.V. Khmelenko, and A.F. Shestakov, Fiz. Nizk. Temp. 23, 753 (1997) [Low Temp. Phys. 23, 567 (1997)].

44. A.G. Belov and E.M.Yurtaeva, Fiz. Nizk. Temp. 27, 1268 (2001) [Low Temp. Phys. 27, 938 (2001)].

45. W.G. Lawrence and V.A. Apkarian, J. Chem. Phys. 97, 2229 (1992).

46. A.A. Radtsig and B.M. Smirnov, Reference Data on Atoms, Molecules, and Ions, Springer, Berlin (1985).

47. O. Oehler, D.A. Smith, and K. Dressler, J. Chem. Phys. 66, 2097 (1977).

48. V.V. Khmelenko, I.N. Krushinskaya, R.E. Boltnev, I.B. Bykhalo, A.A. Pelmenev, and D.M. Lee, Fiz. Nizk. Temp. 38, 871 (2012) [Low Temp. Phys. 38, 688 (2012)].

49. L.G. Piper, L.M. Cowles, and W.T. Pawlins, J. Chem. Phys. 85, 3369 (1986). 


\section{Дослідження механізмів зарядки домішково- гелієвих конденсатів методами спектроскопії імпедансу та струмової спектроскопії}

\section{А.А. Пельменьов, І.Б. Бихало, І.Н. Крушинська, Р.Є. Болтнєв}

Просту експериментальну методику розроблено та успішно випробувано для використання можливостей спектроскопії імпедансу при дослідженні процесів на стадії руйнування зразків домішково-гелієвих конденсатів. Вперше використано комбінацію методів спектроскопії імпедансу, струмової спектроскопії та оптичної спектроскопії для дослідження руйнування домішково-гелієвих конденсатів. Отримані результати показали високу чутливість нової методики та підтвердили появу зарядів (заряджених нанокластерів) на стадії руйнування домішково-гелієвих конденсатів.

Ключові слова: нанокластери, домішково-гелієві конденсати, спектроскопія імпедансу, надплинний гелій, стабілізація іонів і радикалів.

\section{Исследования механизмов зарядки примесь- гелиевых конденсатов методами спектроскопии импеданса и токовой спектроскопии}

\author{
А.А. Пельменёв, И.Б. Быхало, И.Н. Крушинская, \\ Р.Е. Болтнев
}

Простая экспериментальная методика разработана и успешно опробована для использования возможностей спектроскопии импеданса при исследовании процессов на стадии разрушения образцов примесь-гелиевых конденсатов. Впервые использована комбинация методов спектроскопии импеданса, токовой спектроскопии и оптической спектроскопии для исследования разрушения примесь-гелиевых конденсатов. Полученные результаты показали высокую чувствительность новой методики и подтвердили появление зарядов (заряженных нанокластеров) на стадии разрушения примесьгелиевых конденсатов.

Ключевые слова: нанокластеры, примесь-гелиевые конденсаты, спектроскопия импеданса, сверхтекучий гелий, стабилизация ионов и радикалов. 